\title{
EMERALDS OF COLOMBIA
}

\author{
By Peter C. Keller
}

There has been more activity in emerald mining in Colombia in the last few years than at any other time in the four centuries since the Spanish first discovered the deposits. This article combines a comprehensive review of the literature on the history and geology of Colombian emeralds with the author's own insights into the current marketing and mining of these stones. Of particular concern are the harsh methods now being used to extract the emeralds and the impact these methods will have on future production in Colombia. The past, however, has yielded many fabulous gems, the most famous of which are also described here and placed in historical perspective.

\section{ABOUT THE AUTHOR}

Dr. Keller is director of education of the Gemological Institute of America, Santa Monica, CA.

Much of the research for this article was undertaken in preparation for a special exhibit of Colombian emeralds and pre-Columbian gold artifacts held at the Natural History Museum of Los Angeles County July 4-September 6, 1981.

1981 Gemological Institute of America

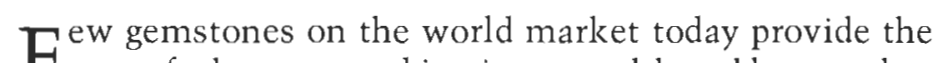
F aura of adventure and intrigue, wealth and beauty that is so intrinsic to emerald. The first records of emeralds worn as jewelry date from the early days of the Roman Empire, in reference to stones recovered from now longlost Egyptian mines. They have been treasured as gems ever since. Although the Egyptian mines may have introduced emeralds to the Western world, historically the finest emeralds have come from deposits in Colombia. The checkered history of these mines began cruelly with the Spanish conquerors' enslavement of local Indians to work the deposits, leading to the decimation of the native population in just a few years. And as recently as the early 1970s, Muzo-the major mine-was forced to close because of over 900 emerald-related murders in one year.

Over the past half century, there have been numerous papers describing the status of the Colombian emerald mines, usually by recent visitors to the mining areas (MacFadden, 1934; Switzer, 1948; Copeland, 1950; Anderton, 1950 and 1965; Bancroft, 1971; and Tenhagen, 1972). However, few, if any, of these papers have combined their observations /which were usually on a single mine) with a comprehensive review of the literature to provide a detailed account of the history and geology of the emerald deposits. Furthermore, in the past five years we hav \ seen more activity in the Colombian mines than there has been since the Spanish first exploited them in the 16 th century. The purpose of this paper is to combine a comprehensive review of the literature with an update on current mining and marketing activity, based on several recent trips to the area by the author. In addition, major emeralds originally mined in Colombia and now

\footnotetext{
The 300-year-old Spanish Inquisition necklace contains 15 emerald beads and more than 360 diamonds. Photograph by Harold and Erica Van Pelt. Courtesy of the National Museum of Natural History, Smithsonian Institute, Washington, DC.
} 


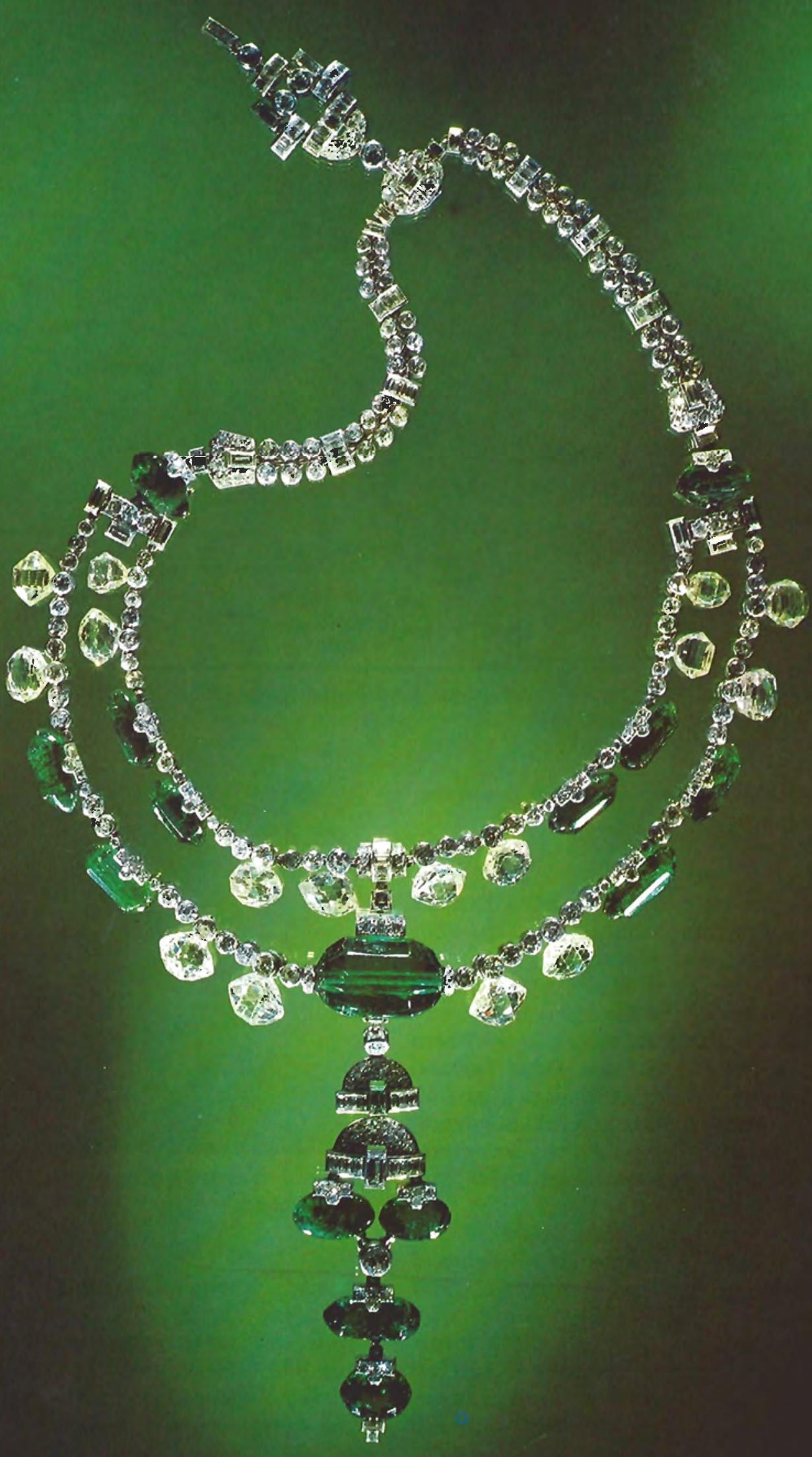




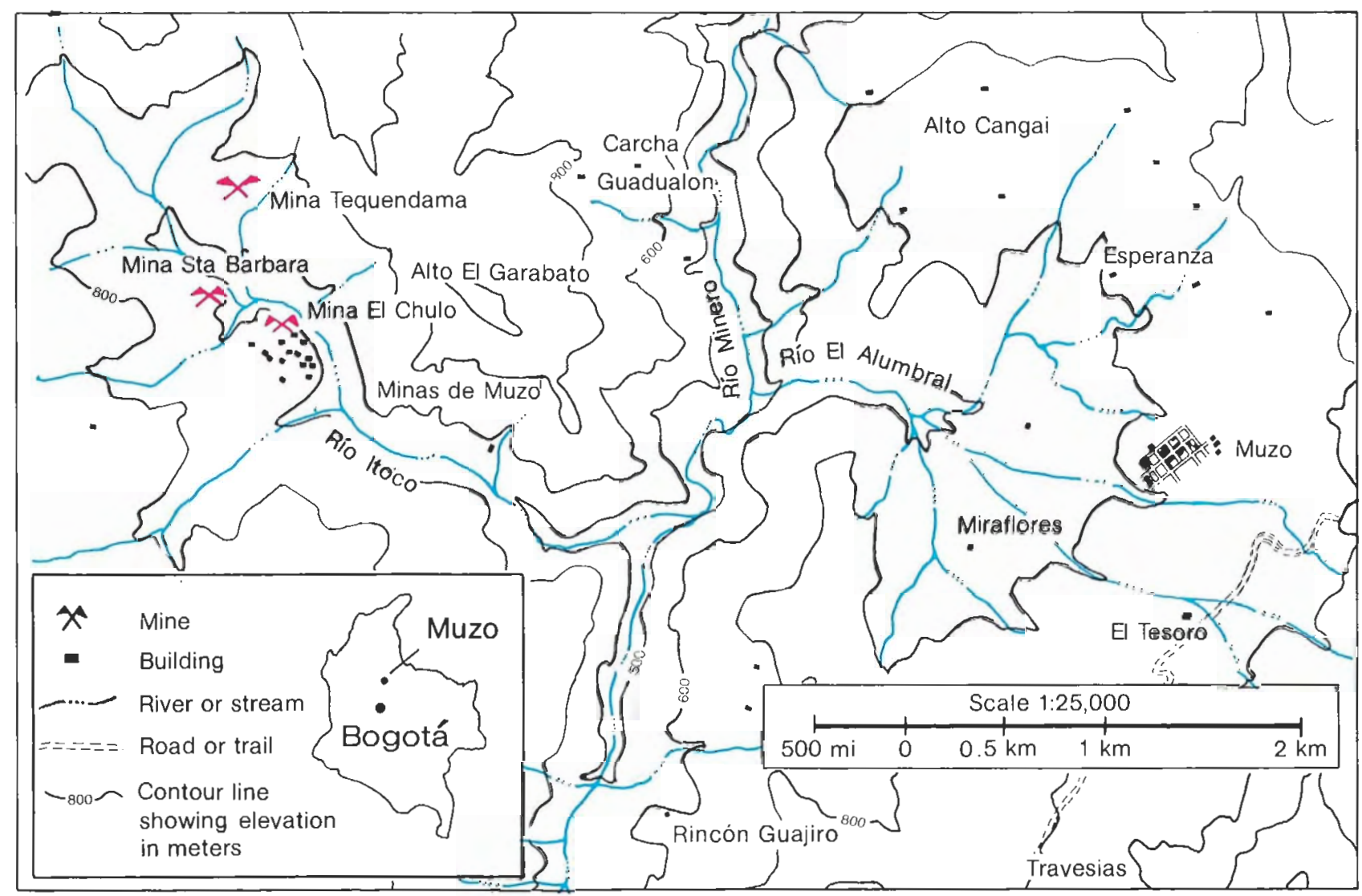

Figure 1. Index map showing the location of the mines and other geographical features of the Muzo district, Boyaca, Colombia.

housed throughout the world will be described, some for the first time.

\section{OVER VIEW}

There are two principal emerald-mining districts in Colombia today: Muzo and Chivor. The 360$\mathrm{km}^{2}$ Muzo district, at an elevation of about 600 $\mathrm{m}$, is located $105 \mathrm{~km}$ north of the capital city of Bogotá in the valley of the Río Itoco, a tributary of the Río Minero. The main mines in the Muzo district include the Tequendama, Santa Barbara, El Chulo, Coscuez, and Peñas Blancas (figure 1). The district is owned by the Colombian government and is currently being worked by several private mining companies operating under fiveyear leases (figure 2).

The Chivor district, located about $75 \mathrm{~km}$ northeast of Bogotá in the Almeida township of Boyaca, is part of the exceedingly rugged country where the Río Rucio and Río Sinai join to form the Rio Guavio (figure 3). Feininger (1970) points out that the mine is at an elevation of about 2300 $m$ and that just $2 \mathrm{~km}$ to the east, in sight of the mine, the Río Guavio, at an elevation of only 700

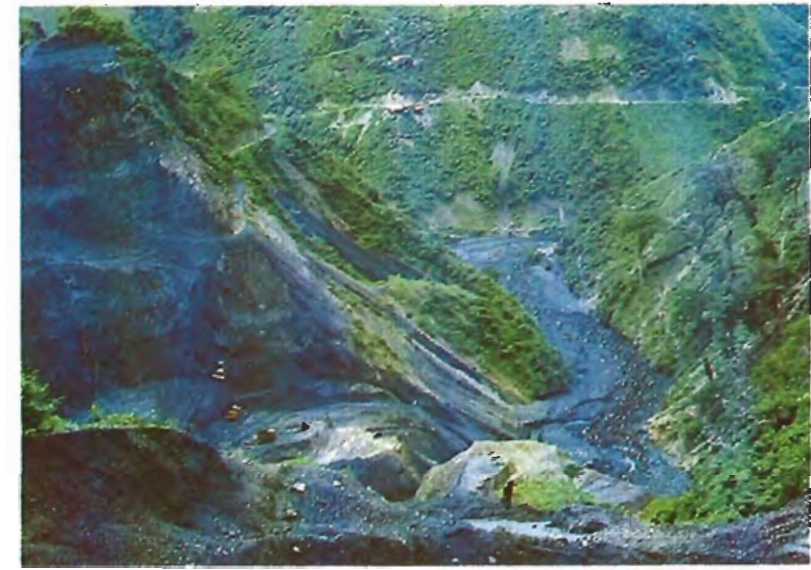

Figure 2. A view looking to the north over the Muzo mines.

$\mathrm{m}$, slices through a ridge that is even higher than the mine (figure 4). In addition to the Chivor mine, the Chivor district includes the Buenavista mine, immediately to the south of Chivor, and the Las Vegas de San Juan mine, located $8 \mathrm{~km}$ to the southwest and commonly known as the 

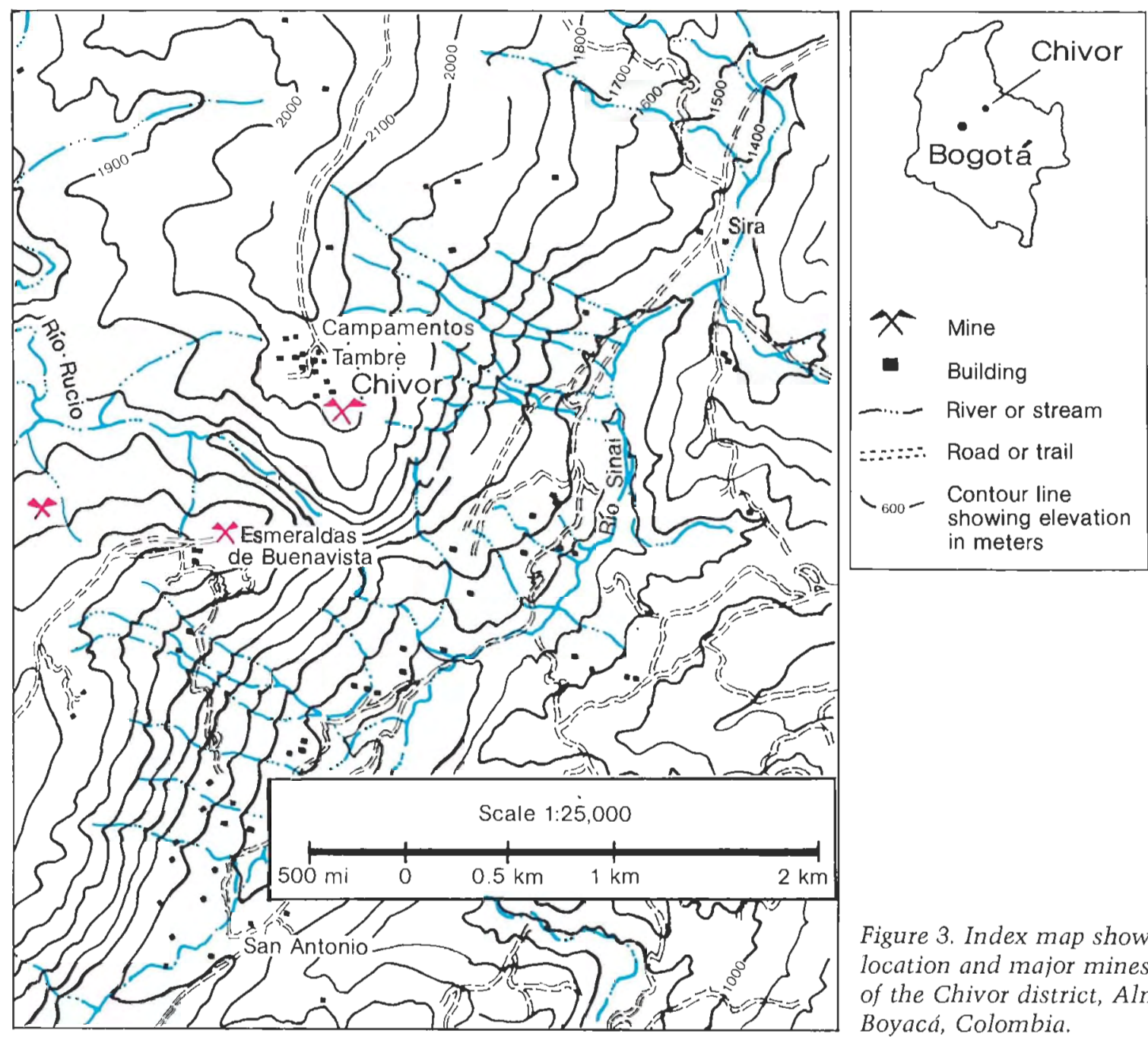

Figure 3. Index map showing the location and major mines and rivers of the Chivor district, Almeida, Boyaca, Colombia.

Figure 4. A view looking east over the Chivor emerald mine, which is situated at an elevation of about $2300 \mathrm{~m}$.

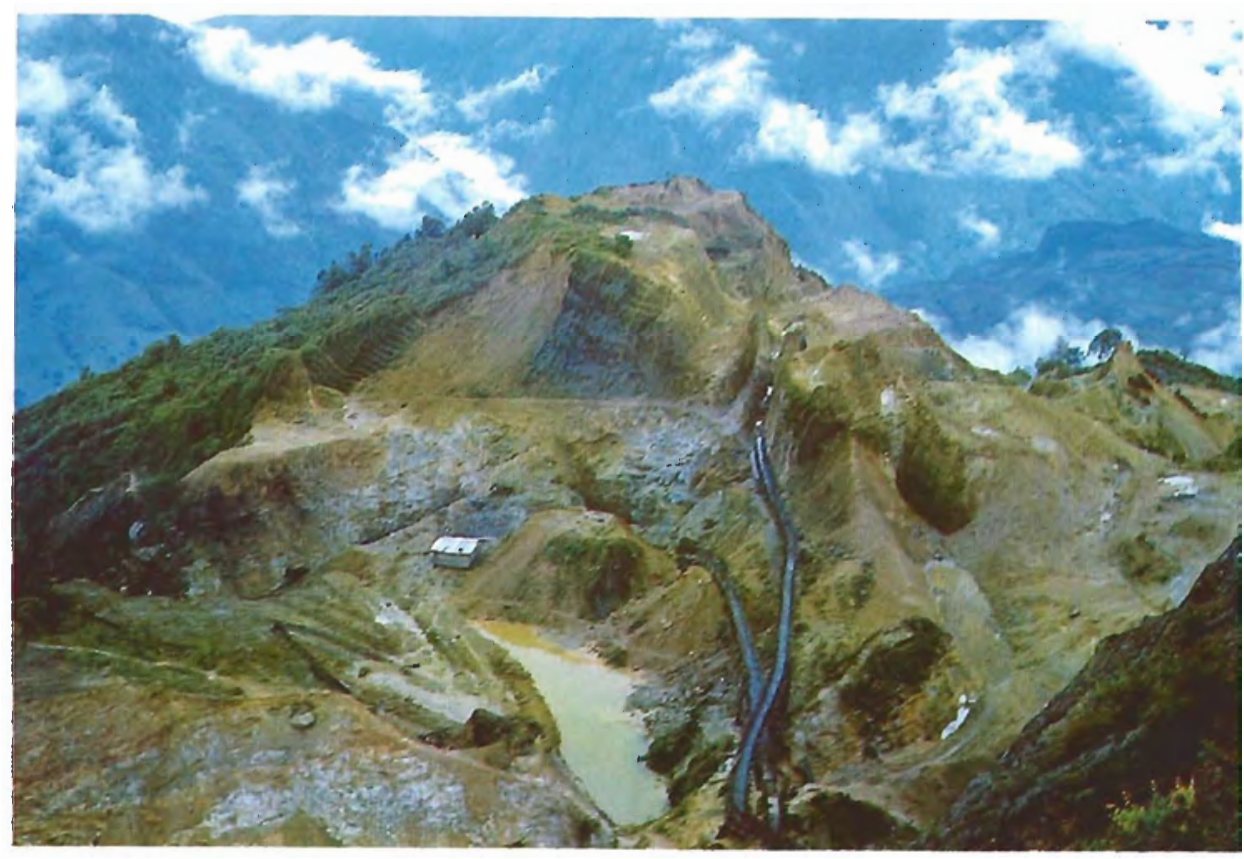


Gachalá mine (Anderton, 1955). The Chivor mine is the only privately owned emerald mine in Colombia. The Buenavista and Gachalá mines operate as concessions under a 1959 law, and their owners pay a $25 \%$ royalty to the Colombian government (Colombian American Business, 1979).

There have been a number of studies on the geology of Muzo and, to a lesser extent, Chivor (see box). Our current knowledge of the geology tells us how the emeralds occur and where to direct future exploration. Thus far, however, a detailed study of the Eastern Cordillera has been inhibited by rugged terrain and thick vegetation, which has also restricted exploration.

\section{EARLY HISTORY}

Emeralds mined in Colombia have been used for trade and personal adornment throughout much of Middle and South America since pre-Columbian times. When the first Spaniards arrived in the New World in the early 16th century, emeralds were being worshiped, were used in jewelry, and played an important role as sacrificial offerings in ceremonies such as the famous El Dorado ceremony on Lake Guatavita, located just northeast of Bogotá (Bray, 1978). Emeralds were being traded as far south as Peru and Chile and as far north as Mexico. According to Morello (1957), when Spanish conqueror Cortes met the Aztec

\section{GEOLOGY OF MUZO AND CHIVOR}

The lower member at Muzo, the Cambiado, consists of highly folded, faulted, and fractured carbonaceous shales and thinly bedded limestones. The Cambiado is discordantly overlain by the Emerald Beds, the latter consisting of thinly bedded, weathered, yellowish-gray shales that have also been intensely folded and invaded by thin calcite veins. The Emerald Beds, as their name implies, contain localized concentrations of emeralds associated with calcite, dolomite, pyrite, quartz, and parisite. Locally, the Cambiado and Emerald Beds are separated by the Cama and the overlying Cenicero. The major difference between these two layers appears to be textural. The Cama consists of an agglomerate of relatively large calcite crystals, whereas the Cenicero, which is usually about a meter thick, consists of small calcite crystals along with pyrite in a carbonate ground mass. Barite has also been reported in the Cenicero (Oppenheim, 1948).

The Colombian Andes consists of three subparallel ranges: the Western, or Cordillera Occidental; the Central, or Cordillera Central; and the Eastern, or Cordillera Oriental. According to Clements (1941), the Western and Central ranges consist primarily of granites and are best known for their gold deposits (gold production). The Eastern range, however, consists mostly of sedimentary units, principally limestones and shales with minor igneous and metamorphic rocks exposed only locally. Clements places a Paleozoic age on these crystalline rocks.

The major emerald deposits are limited to the eastern (Chivor) and western (Muzo) margins of the Cordillera Oriental where Cretaceous sediments are well exposed. The geology of the Muzo district has been described by several authors, five of whom are outstanding: Pogue (1916), Lleras (1929), Scheibe (1933), Clements (1941), and Oppenheim (1948). These studies agree that emeralds are restricted to the Villeta formation of Lower Cretaceous age. The Villeta formation consists of a great thickness of intensely folded and fractured black carbonaceous shale and minor limestones. The black shale is so rich in carbon that it is impossible to handle without soiling one's hands. The Lower Cretaceous age of the Villeta has been determined from the presence of fossil ammonites. The highly fractured shales have been invaded by numerous white calcite fracturefilling veins, and it is in these veins that the emeralds occur. Dolomite, quartz, pyrite, and the uncommon rare-earth calcium carbonate, parisite, are accessory minerals commonly found with emerald in these veins. Lleras (1929), Scheibe (1933), and Oppenheim (1948) noted albite as a common vein mineral at Muzo, but Clements (1941) did not observe albite, nor did this author.

The Villeta formation was divided into two members by Lleras (1929), namely, the Cambiado and the overlying Emerald Beds. Locally, these two members are separated by two thin agglomeratic layers of calcite crystals designated the Cama and the Cenicero (Oppenheim, 1948). 
emperor Montezuma in Mexico in 1519, the latter was bedecked with fine emeralds. Reportedly, Spanish conqueror Pizarro sent four chests of emeralds from Peru to the King of Spain in 1533. These were all undoubtedly of Colombian origin (Ball, 1931).

Chivor was the first operating emerald mine discovered by the Spaniards in their conquest of the New World. Gonzalo Jiménez de Quesada saw the first sign of emeralds in Colombia at Turqmequé, Boyacá, in 1537 (Colombian American Business, 1979). Quesada sent Captain Pedro F. de Valenzuela to find the source. That same year, he located the well-developed Chibcha Indian mine of Somondoco, later to be named Chivor after a nearby valley. Soon thereafter, the Spaniards were vigorously working the Chivor mine using local Indians as slave labor.

Five years after the founding of Santísima Trinidad de los Muzos in 1559 (Wokittel, 1960), the Muzo and Caijma Indians' mine was located some $7 \mathrm{~km}$ to the west on the Itoco Hill. Actual mining of the Muzo area by the Spaniards began in 1567, and initial production is said to have overshadowed production at Chivor (Feininger, 1970). By the end of the 16th century, both Chivor and Muzo were being vigorously worked using Indian slave labor. In 1592, the first recorded grant

The sedimentary rock units at Chivor are somewhat different from those described for Muzo. At Chivor, such units are almost entirely shales and argillites, with minor limestone and sandstone (Rainier, 1929). The general geology and stratigraphy of this area are not as well known as at Muzo. The stratigraphic section at Chivor appears to consist primarily of at least $1000 \mathrm{~m}$ of conformable sediments. A good description of these sediments and the geology is found in Johnson (1961). Johnson indicates that the emerald zone at Chivor runs about $10 \mathrm{~km}$ east-west and about 5 $\mathrm{km}$ north-south. Fossil ammonites, bivalves, and ferns indicate that the sediments of the district are of Cretaceous age. As at Muzo, these sediments are heavily faulted and folded. They are mostly shales and argillites with some blocks or floaters of carbonaceous limestone present near the top of the stratigraphic section. The most prominent unit is a poorly cemented yellowish shale which overlies a thick sequence of gray-blue shales and argillites. No emeralds have been reported from the yellowish shale cap. Most emeralds occur in a blue-gray argillite about midway through the section. Johnson (1961) suggests that the occurrence of emeralds at Chivor is structurally related, as if the emerald veins were concentrated along the axes of tight folds in the argillites. He states that, "If a vein is discovered traveling in the trough of a syncline, the production of stones may be immense."

Chivor emeralds are found mostly in veins, but in rare instances they may occur in cavities, as was the case with the famous Patricia emerald discussed elsewhere in this paper. The cavities, when present, are always associated with the veins. The veins run parallel to the bedding of the sediments, which suggests that separations between bedding laminae provided the avenues of least resistance for fissure-filling hydrothermal solutions that crystallized to form veins. Such veins occur up to $15 \mathrm{~cm}$ in thickness but rarely exceed $65 \mathrm{~m}$ in length. Emeralds commonly are found where two veins intersect. Johnson (1961) divided the veins into three mineralogical types: (1) pyrite, (2) albite, and (3) pyrite with albite. The mineralization is in sharp contrast to the emeraldbearing veins of Muzo, where the gem material occurs in white calcite or dolomite or both. It is stressed that there have been no reports of emeralds occurring in calcite or dolomite at Chivor; both quartz and pyrite are very common there.

Three more-or-less parallel "iron bands," consisting of pyrite and limonite, appear about $50 \mathrm{~m}$ apart from one another, interlaminated in the stratigraphic section at Chivor. These bands appear to control the distribution of emeralds to some extent. Emeralds are most prevalent below the lowest of the three iron bands or between the lowest and middle bands. Very few emeralds have ever been reported above the middle or upper iron bands. This suggests that these bands may have acted as impervious "dams" for the rising emerald-bearing solutions. 
of Chivor was given to Francisco Maldonado de Mendoza by Antonio Gonzalez, president of the New Kingdom of Granada. By this time, however, the treatment of the Indian slaves was so inhumane that on September 22, 1593, President Gonzalez issued a 39 -article decree protecting the Indians (Johnson, 1961). This decree was soon followed in 1602 by several royal orders from Phillip III of Spain to enforce the law. By this time, however, the Indian population had already been decimated. As a consequence of this loss of cheap labor and the litigation that followed the royal orders, production of Colombian emeralds declined drastically. In 1650, the Muzo mines were declared royal property, and production further declined. By 1675, the Chivor mine had been abandoned; its location eventually became a mystery that endured for over 200 years. Muzo continued to be worked sporadically throughout the 17th, 18th, and 19th centuries (Barriga and Barriga, 1973) until the government declared it the National Emerald Domain in 1871 (Colombian American Business, 1979). When the mines at Muzo came under government control, production all but ceased and lawless disorder came to characterize the area. This situation has changed only very recently.

Soon after Muzo was placed under government control, the Chivor mine was rediscovered on the basis of a description written almost 300 years earlier. In 1888, Colombian mining engineer Don Francisco Restrepo found a manuscript dating back to the early 17 th century in a Dominican convent in Quito, Equador. This manuscript, written by Fray Martin de Aguado, described the location of the Chivor mine as the only place in the Andes where one could see through a pass in the mountains to the plains of the Orinoco. Restrepo's search for the legendary mine ended successfully in 1896. Although legal problems with the government hampered Restrepo's early mining activities, his early 20th century partnership with German mining engineer Fritz Klein coincided with the lifting of some of these restrictions and promising production at the mine. When World War I broke out, however, Klein returned to Germany for military service. Restrepo died at Chivor, and, with Germany's loss of the war, Klein lost all rights to the mine as a result of alien property legislation. In 1919, Chivor was purchased by the Colombian Emerald Syndicate, Ltd., an American company. Since then it has changed hands many times with varying degrees of success, and has been managed by such notable mining engineers as Peter W. Rainier (author of Green Fire, 1942) and Willis Bronkie. The Chivor mines are currently in the hands of the Quintero family.

In 1953 , a new mine was discovered $8 \mathrm{~km}$ southwest of Chivor at Gachalá, reportedly when a woodcutter's mule uncovered an emerald-bearing rock (Anderton, 1955). Although the mine has produced only sporadically since 1953, in 1967 an 858-ct. crystal, generally considered one of the finest in existence, was found there. The 5$\mathrm{cm}$ hexagonal prism is known simply as the Gachalá emerald and is housed in the Smithsonian Institution (Trapp, 1969).

\section{RECENT HISTORY AND PRODUCTION}

Emerald mining under government control has been a questionable business proposition. In 1946, the government entrusted the management of the Muzo mines, including the power to regulate all mining and marketing of emeralds from that district, to the Banco de la República /Feininger, 1970|. However, illicit emerald mining and dealing continued to be widespread, with an estimated loss to the government of more than 28 million pesos during the period 1946 to 1969 , when the Bank relinquished control of the Muzo emeralds to the Empresa Colombiana de Minas (ECOMINAS), the government's mining agency. Still, the situation at Muzo worsened, to the point that in 1973 over 900 people were killed in feuds and the mines were forced to close. The mines stayed officially closed until 1977, when the gov-

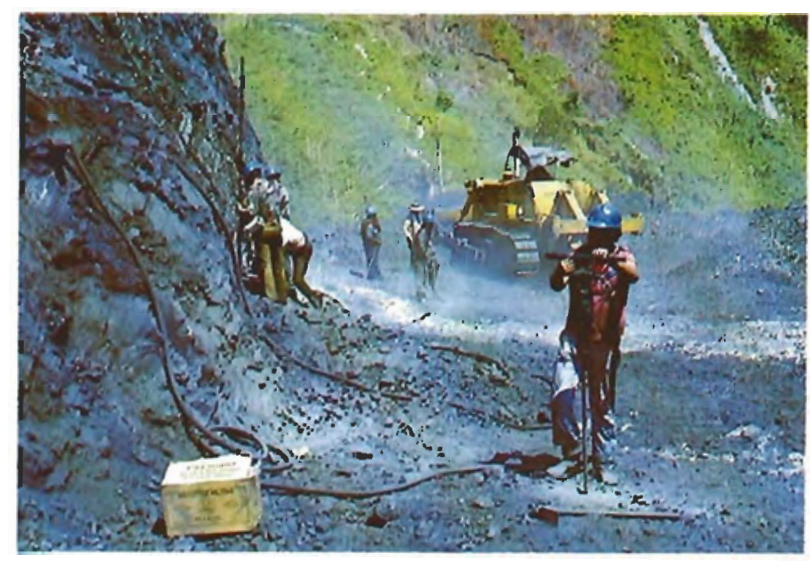

Figure 5. Active mining of emeralds at Muzo. Note the white calcite veins. 


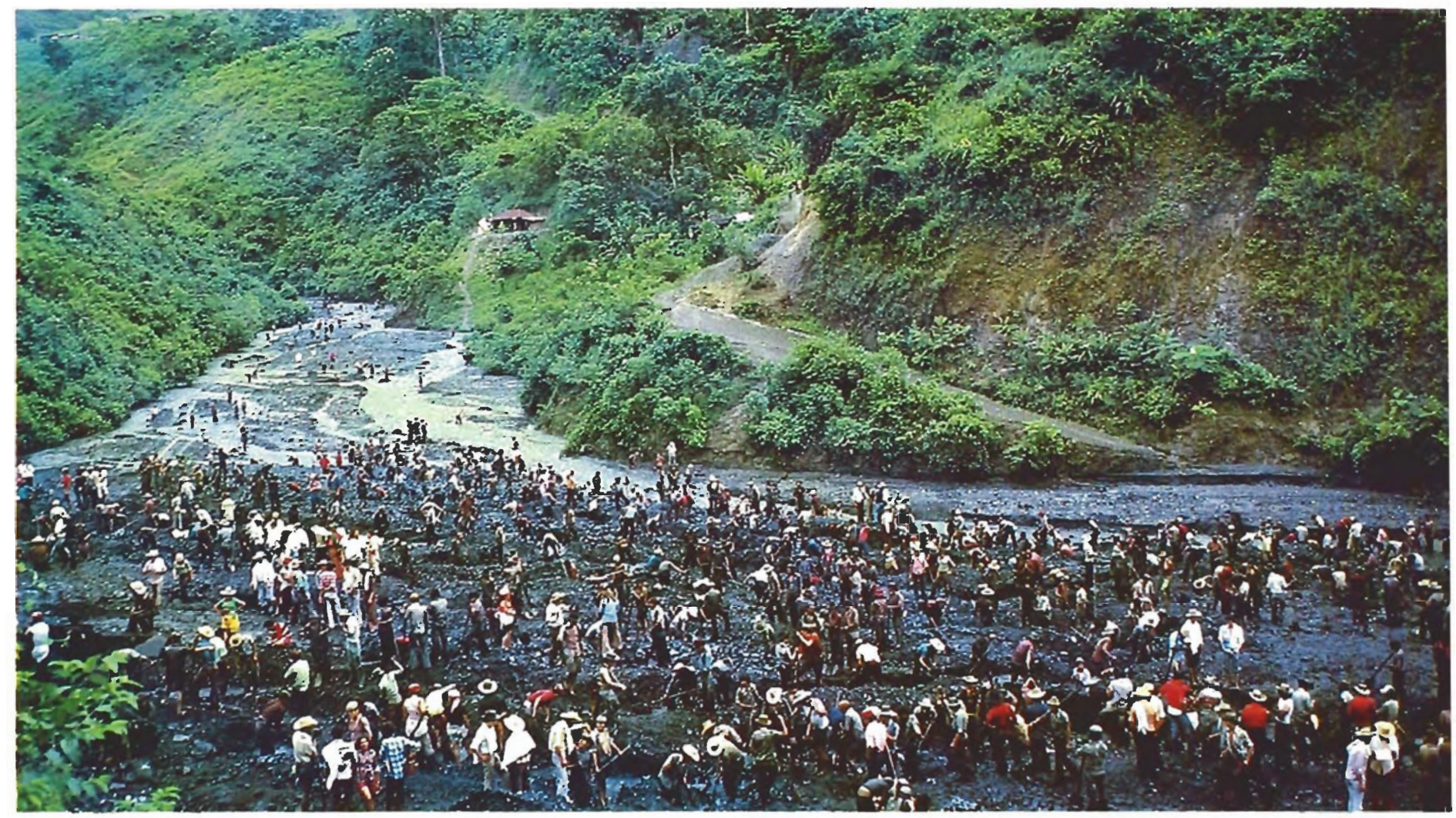

Figure 6. Looking eastward at guaqueros working in the Rio Itoco below the main mining operations at Muzo.

ernment solicited bids for five-year leases on the Muzo mines, the Coscuez mine, and the Penas Blancas mine. After extensive negotiations, the Muzo lease was awarded to the Sociedad Minera Boyacense Ltda., the Coscuez lease went to Esmeraldas y Minas de Colombia, S.A. (ESMERACOLl, and the Peñas Blancas lease went to the Quintero brothers, who also control the Chivor mine (Colombian American Business, 1979).

Unfortunately, five-year leases encourage the lessees to mine the area as rapidly as possible, and their methods are not as conservative of resources as they should be (figure 5). When the author visited Muzo in 1979 and again in 1980, the main area was being worked harshly, using bulldozers and dynamite, a method not adopted in the past because of the fragility of the emeralds. After an area has been blasted, bulldozers scrape off the overburden until the white calcite veins are exposed. Then, teams are brought in to work each vein with pick and shovel. When emeralds are found, they are placed in a canvas bag for sorting by the mine lessees each evening. These sorted parcels are then sealed and taken to Bogotá for further grading and subsequent marketing.
Because the main mine area is being stripped away so rapidly, a significant portion of the potential emerald production is lost to the gravels of the Río Itoco, with the result that an estimated 15,000 guaqueros (independent miners, directly translated as "treasure hunters") mine the riverbed each day (figure 6). These guaqueros usually work alone or in small groups, and they live entirely on what they find. They subsist in nearby rancheros on the flanks of the Itoco Valley, eating pigs, chickens, vegetables, and fruits that they raise or grow locally. Their lifestyle closely resembles that of the miners who joined the mid19 th century California Gold Rush.

The terms of the government leases are very demanding. For example, over five years, ESMERACOL will pay ECOMINAS a total rent of 260 million pesos (about US $\$ 6.53$ million) plus $5 \%$ of the gross production at Coscuez. ESMERACOL started working Coscuez in March of 1978; by 1979 , five bulldozers were working the mine, and a force of 60 National Police patrolled the area to prevent poaching (Colombian American Business, 1975). The status at Muzo is very similar.

Emerald production statistics for Colombia 
during the 1970s, as reported by Baskin in the Minerals Yearbook (1979), provide some indication of what has happened to emerald production since the leases were awarded. In 1973, total exports of emeralds from Colombia were reported to be US $\$ 2$ million. In 1978 , these exports rose to US $\$ 40$ million; and in the first seven months of 1979 , exports rose to US\$75 million. If this trend continues, Colombia should derive far more revenue from emerald mining than ever in the past.

\section{MARKETING THE EMERALDS}

Presently, there are two distinct systems in Colombia for marketing emeralds: (1) the official marketing required by law of the private mining companies under leases from the government, and (2) the illicit marketing done by the guaqueros in the Río Itoco and, to a lesser extent, at other mines. In the case of the private mining companies, the value of their production is determined by the Controloría General de la República, representatives of ECOMINAS, and by the owners of the mining companies. The private mining companies then market their emeralds through whichever channels they choose. The amount of emerald mined and subsequent marketing by the guaqueros working in the Rio Itoco below the main mines at Muzo is much more secretive. When a guaquero finds an emerald, eager buyers are waiting on the dirt road next to the river. These esmeralderos, independent emerald dealers from Bogotá, gather to buy whatever is found in the river, then take their goods to Bogotá to be cut and subsequently traded on the sidewalks off Bogotá's Avenida Jiménez. On any given day, one can see emeralds of any quality and quantity being traded on Avenida Jiménez, ironically, within sight of the Banco de la República.

It is, however, buyer beware when purchasing emeralds on the Avenida Jiménez. Recently, a number of very cleverly enhanced emeralds and "imitations" have been sold to the unwary. These include quartz crystals that have been cored, filled with green plastic, polished, and then glued into a plausible shale matrix; the discreet use of green ink to make moralla, or pale green emerald, appear to be of a fine green color; as well as green glass and plastic imitations.

\section{IMPORTANT COLOMBIAN EMERALDS}

Even though emeralds have been mined in $\mathrm{Co}^{-}$ lombia since pre-Columbian times, relatively few very fine large examples are known today. Because of the extremely high value of faceted stones, fine large emerald crystals are particularly rare. The following is a brief discussion of what many would agree are some of the most important emeralds, both cut and uncut, produced by the Colombian mines.

During the 17 th century, large Colombian emeralds were eagerly sought by the Mogul nobility of India. By way of Spain, a great many of the early Colombian stones found a ready market in India through well-established trade routes. One particularly fine example of these emeralds is the "Mogul" (see cover), which is currently owned by private collector Allan Caplan. The Mogul emerald measures $5 \mathrm{~cm} \times 3.8 \mathrm{~cm} \times 3.5 \mathrm{~cm}$ and weighs $217.8 \mathrm{cts}$. (Caplan, 1968). The front of the stone is carved with the floral motif typical of the Mogul carvers; the back contains an Islamic prayer and includes the date 1695 A.D. The drilled stone was probably worn on an article of clothing, perhaps a turban.

Many of these Colombian emeralds were taken from India in 1739 during the sacking of Delhi by the Persians, and now are part of the Crown Jewels of Iran in Tehran. Meen (1969) examined over one thousand of these emeralds and reported that most were over $10 \mathrm{cts}$. and some exceeded 300 cts. (Meen and Tushingham, 1968). Certainly this collection and the collection in the Topkapi Museum in Istanbul, Turkey, must be considered the two largest collections of Colombian emeralds in the world.

One of the most spectacular pieces of emerald jewelry on public display in the United States is the 300-year-old Spanish Inquisition necklace (see frontispiece), which is in the Smithsonian Institution's collection. This necklace was reportedly worn in the Spanish and, later, French courts. The drilled hexagonal and cylindrical beads that make up the necklace may very well have originally belonged to articles of pre-Columbian jewelry and were simply reset in to this magnificent piece. A $24 \mathrm{~mm} \times 15 \mathrm{~mm}$ drilled emerald bead forms the focal point of the necklace; in addition, there are 14 smaller emerald beads averaging $16 \mathrm{~mm} \times 7 \mathrm{~mm}$. Dunn (1975) reports that the necklace also contains over 360 mine-cut diamonds, 16 of which must be considered major gems themselves. It is interesting to note that these 16 large diamonds also have been drilled.

Another spectacular Colombian emerald in 


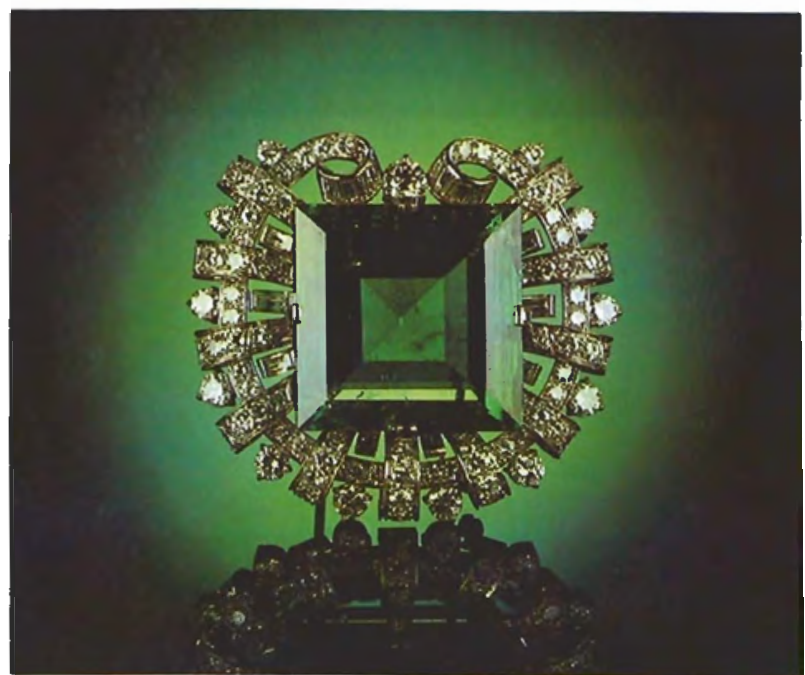

Figure 7. The 75-ct. Hooker emerald, now at the Smithsonian, is remarkably free of the inclusions normally associated with such large stones. Photo courtesy of the National Museum of Natural History, Smithsonian Institution, Washington, DC.

the Smithsonian collection is the 75 -ct. squarecut stone in the Hooker brooch (figure 7). This stone is particularly significant because it lacks the internal flaws that are so typical of large emeralds (Desautels, 1979).

Fine, large emerald crystals are very rare in nature and, because of their inherent value as cut

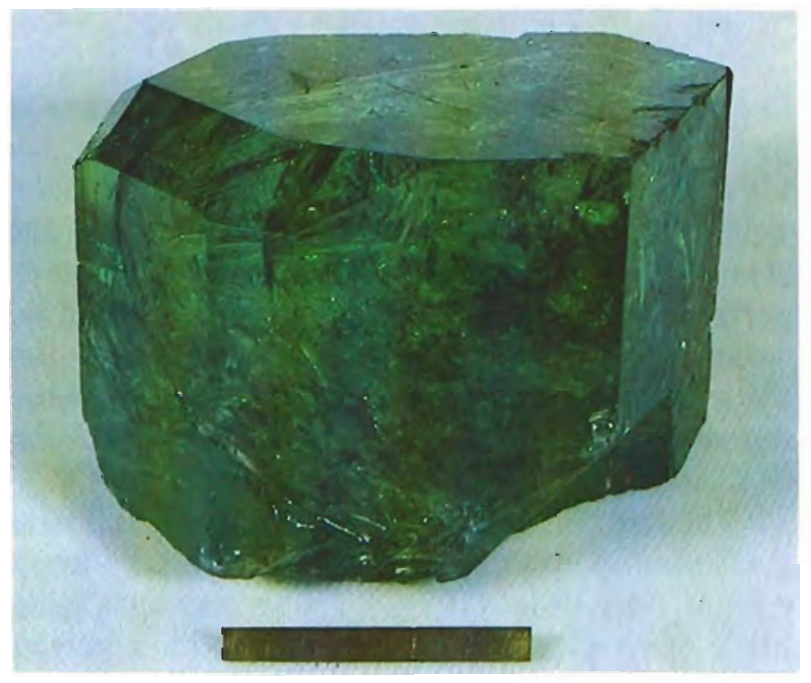

Figure 8. Reportedly the finest emerald crystal in the world is this 858-ct. specimen from the Vega de San Juan mine at Gachalá, near Chivor. The specimen is part of the collection at the Smithsonian Institution. Photo by Rock H. Currier.

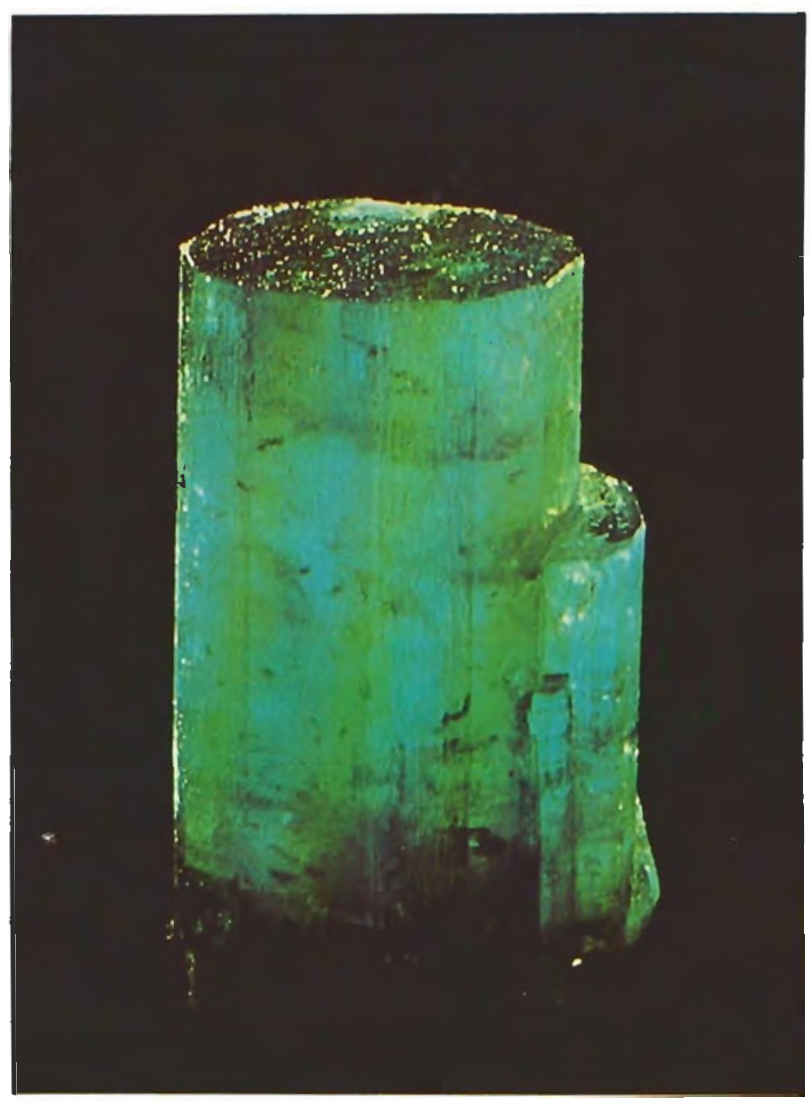

Figure 9. A very fine example of a Chivor emerald is the 632-ct. Patricia found in December 1920 and now housed in the American Museum of Natural History. Photo courtesy of the American Museum of Natural History, New York, NY.

stones, rarely survive intact in the marketplace. There are, however, a few that are worth noting. Reputedly, the finest Colombian crystal in the world is not from Muzo or Chivor, but rather from the recently discovered Gachalá mine (figure 8). This fine hexagonal prism weighs $858 \mathrm{cts}$. and is of unusually fine color and luster. It, too, is part of the gem collection at the Smithsonian Institution (Trapp, 1969).

Several emerald crystals have acquired names through the years. The most famous, perhaps, is the 632-ct. Patricia emerald (figure 9), which was discovered by Justo Daza in December 1920 at the Chivor mine. The Patricia is the largest known emerald from Chivor and was sold early in 1921 for US $\$ 60,000$. It is interesting to note that Justo received a US $\$ 10$ bonus for finding the crystal. According to Johnson (1961), the blast that uncovered the Patricia destroyed a pocket that, when examined, contained fragments of an emerald crystal that was probably even larger. The Patricia 


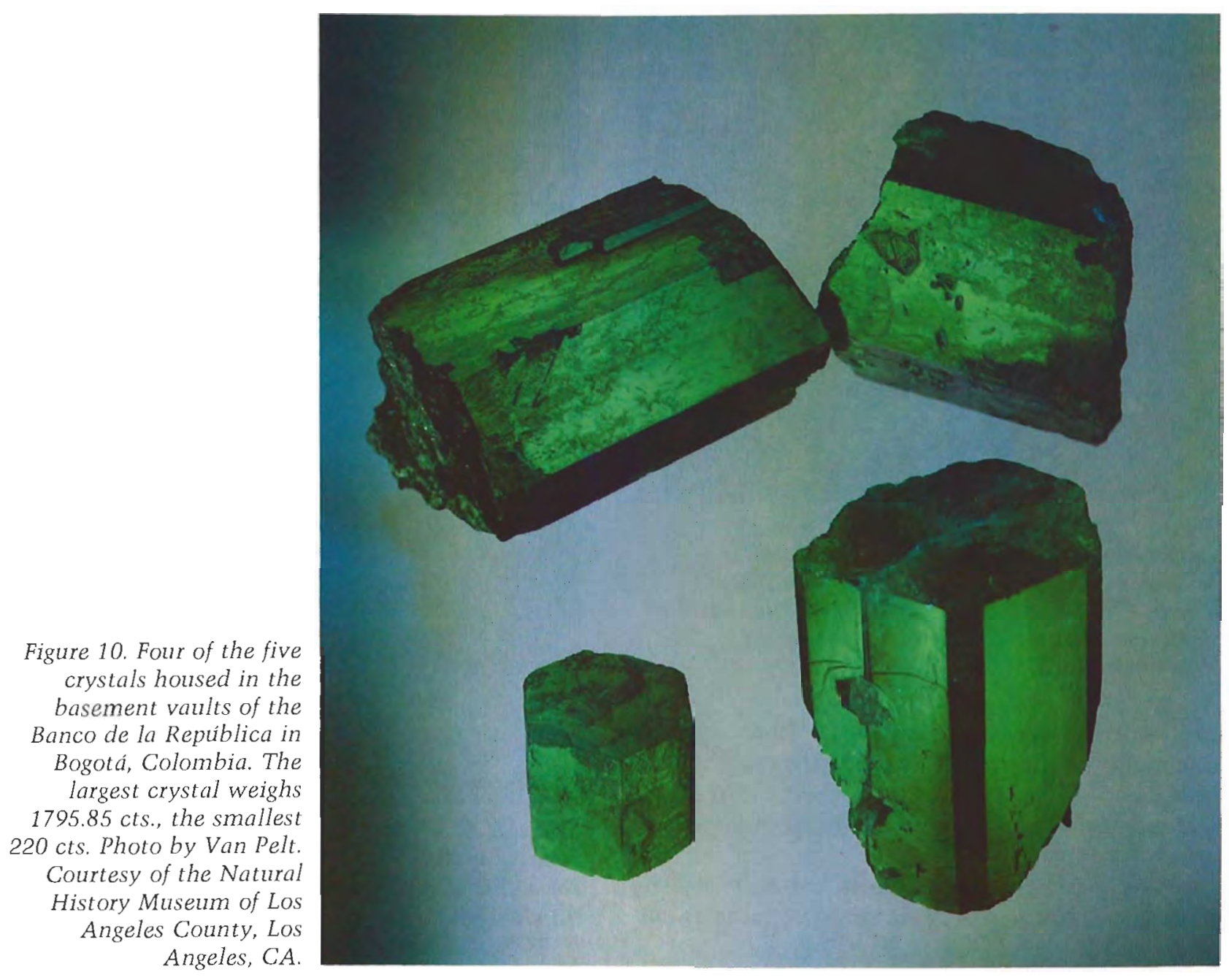

was donated to the American Museum of Natural History in the early 1950 s.

Another named crystal is the famous Devonshire emerald, which was loaned to the British Museum of Natural History in 1936. The current whereabouts of the stone are unknown; the curator of the museum's gem collection recently verified that they have only a wax model. In 1936, the 1384-ct. Devonshire emerald was the largest known emerald from the Muzo mine. Reportedly, the Devonshire is so named because it was given by Pedro I, Emperor of Brazil, to the sixth Duke of Devonshire sometime after 1831, when Pedro I was forced to leave Brazil for Europe. The simple hexagonal prism is approximately $5 \mathrm{~cm} \times 5 \mathrm{~cm}$. It is pictured in Tremayne (1936).

The size and importance of the Patricia and Devonshire emerald crystals is somewhat overshadowed by the collection of unnamed crystals housed in the basement vaults of the Banco de la
República in Bogotá. This collection consists of five crystals ranging in size from $220 \mathrm{cts}$. to $1795.85 \mathrm{cts}$. (figure 10). The finest is an extraordinary 1759-ct. crystal with excellent color and crystal form (figure 11). All of the crystals are reportedly from Muzo and were probably found between 1947 and 1969, when the bank controlled the mines, although their history is not well documented. These crystals are not on public display in Colombia.

The largest known single emerald crystal from Colombia is the 7025-ct. Emilia crystal discovered in 1969. It is reportedly from the Las Cruces mine (near Gachalá) and is owned by a private mining concern. It has been displayed at expositions around the world, although its current whereabouts are unknown.

There are undoubtedly many other major emeralds in vaults around the world. I have simply presented here a description of some of the better- 


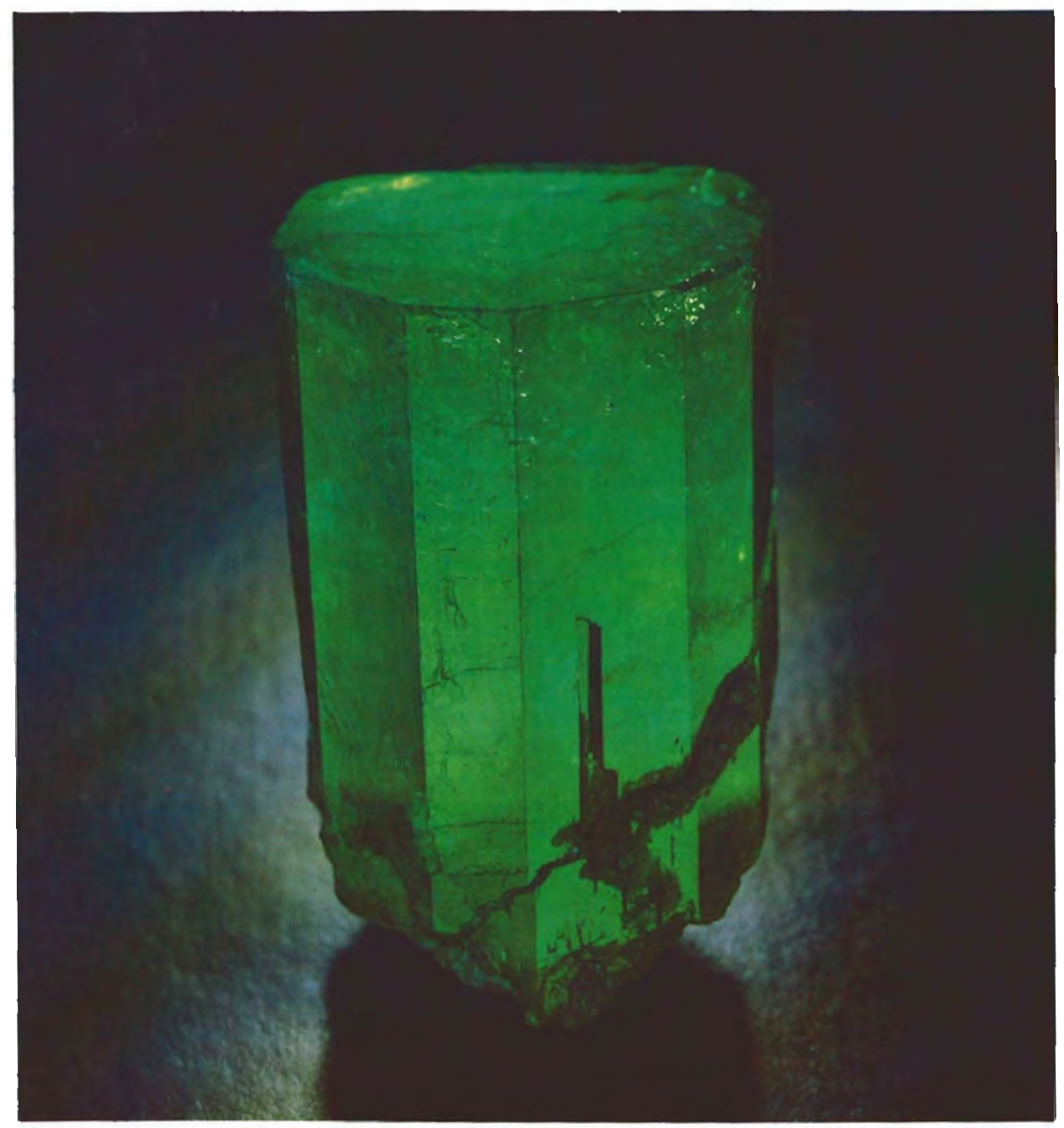

Figure 11. The finest specimen in the collection of the Banco de la Republica is this 1759-ct. crystal of exceptional color and form. Photo by Van Pelt. Courtesy of the Natural History Museum of Los Angeles County, Los Angeles, $C A$.

known stones. With the increased mining activity at Muzo, it is worth contemplating when the next major emerald will be found, and whether it will be preserved for the public to enjoy.

\section{CONCLUSION}

Since the Spanish first started mining emeralds in Colombia in the early 16th century, the two major deposits at Muzo and Chivor have had a checkered history. With the awarding of leases to private concerns in 1977 in the Muzo district, we are seeing what appears to be unprecedented emerald production. At the same time, however, we are also seeing what could be considered reckless mining procedures with the use of dynamite and large numbers of bulldozers. Some reports suggest that these procedures may result in the depletion of the deposit in the very near future. This remains to be seen.

Unfortunately, little detailed work has been done on the geology of the Colombian emerald deposits since the early part of this century. As a result, we have little feel for how extensive the deposits are and what reserves we may expect for the future. Because of the very rugged terrain and dense vegetation and overburden, exploration and mapping are difficult. It is conceivable that these deposits are widespread and that the reserves are actually quite large. Certainly, the presence of what we consider relatively small deposits such as Coscuez near Muzo and Gachalá near Chivor suggests that the emerald-bearing units may be equally as widespread, and gives promise of a bright future for Colombian emeralds for some time to come.

\section{REFERENCES}

Anderton R.W. (1950) Report on Chivor emerald mine. Gems (4) Gemology, Vol, 6, pp. 276-277. 
Anderton R.W. (1955) The new Gachalá emerald mine in Colombia. Gems \&) Gemology, Vol. 8, pp. 195-196.

Anderton R. (1965) The present status of Colombian emerald mining. Lapidary Journal, Vol. 19, pp. 374-377.

Ball S.H. (1931) Historical notes on gem mining. Economic Geology, Vol. 26, pp. 681-738.

Bancroft P. (1971) The lure of Chivor. Lapidary Journal, Vol. 25, pp. 128-131.

Barriga Villalba A.M., Barriga del Diestro A.M. (1973) La Esmeralda de Colombia. Colegio Mayor de Muestra Señora del Rosario, Bogotá.

Baskin G.D. (1979) Gemstones. In Minerals Yearbook, U.S Bureau of Mines, Washington, DC, p. 9.

Bray W. (1978) The Gold of El Dorado. London Times, Ltd. London.

Caplan A. (1968) An important carved emerald from the Mogul period of India. Lapidary Journal, Vol. 22, pp. $1336-$ 1337.

Clements T. (1941) The emerald mines of Muzo, Colombia. Gems and Gemology, Vol. 3, pp. 130-133.

Colombian American Business (1979) Coscuez, an emerald mine reborn. Vol. 18, p. 6.

Colombian American Business (1979) Colombian emeraldsthe little green stone questions. Vol. 18, pp. 3-5.

Colombian American Business (1979) The troubled history of Colombian emerald mining. Vol. 18, pp. 8-9.

Copeland, L.L. (1950) Emerald mine report from Colombia. Gems \& Gemology, Vol. 6, p. 316.

Desautels, P.E. (1979) The Gem Collection. Smithsonian Institution Press, Washington, DC

Dunn P. (1975) Emeralds in the Smithsonian gem collection. Lapidary Joumal, Vol. 29, pp. 1572-1575.

Feininger T. (1970) Emerald mining in Colombia: history and geology. Mineralogical Record, Vol. 1, pp. 142-149.

Johnson P.W. (1961) The Chivor emerald mine. Journal of Gemology, Vol. 8, pp. 126-152.
Lleras C.R. (1929) Minas de Esmeraldas. Boletín de Minas y Petroleos, Vol. 1, No. 1.

MacFadden C.K. (1934) Emerald mining in Colombia. Gems (4) Gemology, Vol, 1, pp. 149-154.

Meen V.B., Tushingham A.D. (1968) Crown Jewels of Iran University of Toronto Press, Toronto.

Meen V.B. (1969) The larger gems of the crown jewels of Iran Gems \&) Gemology, Vol. 13, pp. 2-14.

Morello T. (1957) Green treasure of the Andes. Noture Magazine, Vol. 50 , pp. 512-515.

Oppenheim V. (1948) The Muzo emerald zone, Colombia, S.A Economic Geology, Vol. 43, pp. 31-38.

Pogue J. (1916) The emerald deposits of Muzo, Colombia Transactions of the American Institute of Mining and Metallurgical Engineers, Vol. 55, pp. 810-834.

Rainier P.W. (1929) The Chivor-Somondoco emerald mines of Colombia. Technical Publication No. 258, American Institute of Mining and Metallurgical Engineers, New York, NY.

Rainier, P.W. (1942) Green Fire. Random House, New York, NY.

Scheibe R. (1933) Informe geológico sobre la mina de esmeraldas de Muzo. Compilación de los Estudios Geológicos Oficiales en Colombia, Vol. 1, pp. 169-198.

Switzer G. (1948) Recent emerald production of Colombia. Gems \&) Gemology, Vol. 6, pp. 25-26.

Tenhagen J.W. (1972) Muzo emerald mine, Colombia. Gems 4) Gemology, Vol. 14, pp. 77-81.

Trapp F.W. (1969) The Gachalá emerald shares the spotlight with the Hope diamond at the Smithsonian. Lapidary Journal, Vol. 23, p. 628

Tremayne A. (1936) The Devonshire emerald in Natural History Museum. Gemmologist, Vol. 6, pp. 98-99.

Wokittel R. (1960) Esmeralda. Colombia lnstituto Geológico Nacional, Sección de Geología Económica. 